\title{
IRF1 Gene
}

National Cancer Institute

\section{Source}

National Cancer Institute. IRF1 Gene. NCI Thesaurus. Code C24520.

This gene plays a role in the transcriptional activation of target genes. It is also involved in promoting apoptosis. 